\title{
LA POESÍA DE JUAN CHABÁS EN EL CONTEXTO DE LA VANGUARDIA HISPÁNICA: TRADICIÓN E INNOVACIONES
}

\author{
FRANCISCO JAVIER DÍEZ DE REVENGA \\ Universidad de Murcia
}

\begin{abstract}
En el amplio, y cada vez mejor estudiado territorio de la vanguardia histórica en España, que se desarrolló entre 1915 y 1936, la existencia de numerosas figuras de escritores, y en particular de poetas, que han recibido el apelativo de secundarios, e incluso de menores, hace cada vez más apasionante el conocimiento profundo de toda aquella inmensa manifestación artística, caracterizada por la singularidad, el excentricismo y los afanes de ruptura con todo lo establecido. Vamos conociendo mejor todo este mundo conforme se van publicando reediciones facsimilares de las principales revistas literarias del momento que con tanta fecundidad proliferaron en la España del momento, aunque su carácter efímero, y además su circunscripción a círculos muy limitados, las hace de escasa consulta por los especialistas y por los historiadores de la literatura que, como tantas veces, han hecho historia de los libros. Pero es lo cierto que la primera vanguardia alumbró muy pocos libros, y estos de tan escasísima tirada y en editoriales tan recónditas, que reconstruir aquella historia está resultando un trabajo que no por laborioso deja de ser del máximo interés. Las revistas literarias, entonces, son de primerísimo valor para entender todo este mundo y establecer las valoraciones adecuadas dentro de la historiografía literaria del siglo XX.
\end{abstract}


Vienen a cuento estas reflexiones introductorias porque hay escritores, o hay poetas que han merecido poco interés por parte de los estudiosos de la literatura general, y han quedado reducidos a investigadores especializados en ellos mismos. Es lo que ocurre con el poeta Juan Chabás, autor de una estimable y muy interesante obra poética inicial hoy prácticamente olvidada, sin duda porque su obra posterior, narrativa o ensayística ha merecido una mayor consideración por parte de los estudiosos.

Pero lo cierto es que la figura de Juan Chabás, sobresaliente en el mundo de la vanguardia por su obra en prosa tanto narrativa como ensayística, interesa también como creador de una obra poética vanguardista, que, aunque muy breve, responde bien a sus afanes innovadores. Como tantos otros, muchas veces postergado a un segundo plano, o considerado un poeta menor, caminó junto a los renovadores de la literatura de su tiempo y contribuyó con su obra al logro de nuevos horizontes literarios ${ }^{1}$. En la presente ponencia nos proponemos llevar a cabo el análisis de poemas publicados por Chabás en las revistas de la primera vanguardia, a partir de 1921 y hasta 1928, cuando da a conocer en una revista de Valladolid y en otra de Huelva, todavía, poemas adscribibles al arte de vanguardia. Sin duda, todas estas composiciones han de resultar suficientemente iluminadoras sobre las evoluciones y vaivenes de su insegura trayectoria como poeta. En efecto, los poemas publicados en aquellos años nos muestran a un anhelante y juvenil escritor que busca una identidad que posiblemente no llegó a lograr. Tienen estas composiciones también un interés documental indudable, ya que algunos de estos poemas, no han sido conocidos hasta la reciente publicación de los facsímiles de las correspondientes revistas.

Su primer libro, Espejos 2, recoge los poemas iniciales y tiene el mérito de ser uno de los pocos libros íntegramente ultraístas. Javier Pérez Bazo, rechazando las clasificaciones de ultraísta (hecha por Gloria Videla ${ }^{3}$ ) y de "laxo, cansino y simplista" (realizada por Guillermo de Torre ${ }^{4}$ ), considera, sin embargo, que "encierra no pocas características de aquella estética, si bien es permeable asimismo a valores literarios determinantes en la España de la época [...] Su redacción responde de modo convergente, por un lado, a la conmoción artística que supuso la moda ultraísta y su tropismo; por otro, en él confluyen

\footnotetext{
1 Ver F. J. Díez de Revenga, La poesía de vanguardia, Madrid, Laberinto, 2001, pp. 115-117.

2 J. Chabás y Martí, Espejos, Madrid, Galatea, 1921. Se publicó en la misma colección y editorial, de Don Manuel Machado, que Poemas puros, poemillas de la ciudad, de Dámaso Alonso, quien relata, en páginas inolvidables de Poetas españoles contemporáneos, la visita a don Manolito Machado para pedirle que publicara ambos volúmenes juveniles en su editorial (Madrid, Gredos, 1969, p. 66 y 69).

${ }^{3}$ G. Videla, El ultraísmo. Estudios sobre movimientos poéticos de vanguardia en España, Madrid, Gredos, 1971, p. 186.

${ }^{4}$ G. de Torre, Historia de las literaturas de vanguardia, Madrid, Guadarrama, 1965, p. 100.
} 
tanto el eco modernista como las soluciones de purismo poético" 5. En 1923 anunció la aparición (en 1922) de un segundo libro poético, Ondas, que no llegó a publicar; en él, sin duda, pretendía recoger todas las poesías que dio a conocer en aquellos años en las revistas, y en las que fue transitando desde el ultraísmo hacia un personal cultivo del neopopularismo, tal como se advierte en sus colaboraciones en el Suplemento Literario de La Verdad 6, como estudié en un libro mío de 1979 7. Pero esos son ya poemas más tardíos, de 1924. En 1927, cuando colabora en Verso y Prosa ${ }^{8}$, aunque todavía da a conocer algunas canciones, sus textos más representativos serán ya fragmentos de novelas que en ese momento estaba escribiendo o tenía escritas. Justamente en ese mismo 1927 participó en el acto gongorino del Ateneo de Sevilla, donde se fotografió con sus amigos en la famosa instantánea que ha dado tantas vueltas al mundo. A partir de ese año, desencantado posiblemente por lo poco innovadora que resultaba su poesía, se dedicó a la novela, en cuyo ámbito alcanzó reconocimiento, así como al ensayo9.

¿Contribuiría a este desencanto la burla de que fue objeto, cuando vio dos de sus canciones, que habían aparecido en 1927 en Verso y Prosa, incluidas en 1928, en la Tontología de Gerardo Diego, aunque atribuidas erróneamente a Dámaso Alonso? Más adelante nos referimos a este curioso episodio totalmente olvidado, casi tanto como la misma Tontología de la revista Lola, una de las ideas más felices y estimulantes que surgieron en aquellos brillantes años de poesía y amistad. Sea como fuere, Meseta ${ }^{10}$ recogería, en 1928, todavía tres poemas suyos de corte neopopular, los titulados "Playa", "Liliana" y "Viento", indudablemente ya en esa fecha muy trasnochados, seguramente porque Chabás los entregó con anterioridad. Del mismo modo, y también en el mismo 1928, Papel de Aleluyas, daría a conocer otros cuatro poemas de carácter galante y neopopular. Ambas revistas publicaban las colaboraciones de Chabás en sus números del mes de abril. Aunque las poesías de Chabás han aparecido en

\footnotetext{
${ }^{5}$ J. Pérez Bazo, Juan Chabás y su tiempo. De la poética de vanguardia a la estética del compromiso, Barcelona, Anthropos, 1992, p. 56.

6 Suplemento Literario de La Verdad, edición de F. J. Díez de Revenga, Murcia, Academia Alfonso X el Sabio, 1990.

7 F. J. Díez de Revenga, Revistas murcianas relacionadas con la generación del 27, Murcia, Academia Alfonso X el Sabio, 1979, p. 106.

8 Verso y Prosa, Revista de la "Joven Literatura", edición de F. J. Díez de Revenga, Murcia, Chys Galería de Arte, 1976.

9 Novelas: J. Chabás, Sin velas desvelada, Barcelona, Gustavo Gili, 1927; Puerto de sombras, Madrid, Caro Raggio, 1928; Agor sin fin, Madrid, Ulises, 1930; Puerto de sombras. Agor sin fin. edición de J. Pérez Bazo, Madrid, Espasa, 1998. Y también, en ensayo: Vuelo y estilo, Madrid, Sociedad General Española de Librería, 1934.

${ }^{10}$ Meseta, en Tres revistas vallisoletanas de vanguardia. Meseta (1928-29), DDOOSS (1931) y A la Nueva Ventura (1934), edición de A. Corral Castanedo, Valladolid, Ateneo de Valladolid, 1984.
} 
algunas antologías, no disponemos de edición de obras completas 11, por lo que hay que seguir yendo a estas revistas para leer los poemas que publicó Chabás en estos años.

Sus primeros poemas aparecen en la revista España, en los primeros días de 1921. Así, “Tormenta" en el número 296 (de 1 de enero) y "Bebé" en el número 297 (de 8 de enero). También la revista Vltra ${ }^{12}$ dio a conocer algunos de sus poemas de los primeros años veinte. Todas estas composiciones nos muestran a un poeta deslumbrado por los nuevos escenarios, por la vida moderna y por los inventos que la pueblan. Aunque, fuera de la ortodoxia ultraísta, tiende a mostrar la presencia de sentimientos de nostalgia o melancolía. La vida urbana es la protagonista de algunas de estas representaciones, como en el poema "Ciudad llovida en invierno" (Vltra, 14, 20 de junio de 1921), en el que las imágenes creacionistas realizan el papel establecido en sus avanzados cánones:

Un espejo de agua en los ojos puros de la ciudad, estaba invirtiendo la imagen de las calles.

Las aceras calcaban la desnudez mojada de las cosas.

Y todos los paraguas eran cúpulas buenas para nuestras palabras.

Sobre la base de la pura imagen, deformada por los espejos, de manera que la ciudad aparece invertida, el poema encuentra finalmente otra metáfora formal (paraguas=cúpulas) para contener la bondad de la palabra poética. Una de las obsesiones del poeta, los espejos, que dio título a su primer libro, aparecido al mismo tiempo que este poema, se hace presente en este cuadro urbano, en el que la voz "imagen" forma parte de su propio vocabulario, mostrando la posibilidad de "crear" otra ciudad. En el número siguiente, una nueva representación del espectáculo de la lluvia queda reflejada en “Tormenta" (Vltra, 15, 30 de junio de 1921):

\footnotetext{
11 J. Chabás, Sueño perseguido (Antología poética), edición de J. Pérez Bazo, Aitana, Alicante, 1998; ver también: J. Pérez Bazo, Juan Chabás y Martí. Vida y obra, Denia, Ayuntamiento de Denia, 1985; y Juan Chabás y su tiempo. De la poética de vanguardia a la estética del compromiso, citado.

12 Vltra, Madrid, 27 de enero de 1921-15 de marzo de 1922, edición de J. A. Sarmiento y J. M. Barrera, Madrid, Visor-Comunidad de Madrid, 1993.
} 
La poesía de Juan Chabás en el contexto de la vanguardia hispánica: tradición ...

Brandaban por el cielo

las nubes

como en un naufragio de velas sucias

La noche

se había vestido de ropas viejas

Estaban las estrellas en la calle

y en las lámparas hondas

de los balcones

abiertos

Mi alma

como una niña triste

por todos los rincones

La relación, neorromántica o neosimbolista, de paisaje y estado de ánimo, inevitable en el Chabás juvenil, no impide, sin embargo, el recreo en las imágenes vanguardistas que pueblan la ciudad. El galicismo inicial intenta sorprender, en su inocente novedad, con un toque cosmopolita no muy conseguido, en verdad. En otro poema también de Vltra (19, 1 de diciembre de 1921) titulado "Calle larga", muestra nuevamente su capacidad de creación de imágenes, entre cubismo y greguería, como tantos otros hacían en la misma revista. Pero un tono de nostalgia melancólica, quizá juanramoniano, mostraba ya, en 1921, que Chabás partía hacia otros destinos:

Calle larga, nave

de nuestro soñar;

el alma se va sonámbula

por tus aceras de la madrugada.

Los árboles desnudos, secos, tejen madejas de estrellas

que se cuelgan de sus ramas.

Pasan

los tranvías vacíos, que se llevan

la dormida ciudad a su cochera. 
Y las lucecillas de los portales

cantan y juegan

con los reverberos y las estrellas.

\author{
Y el alma — pisadas huecas- \\ tristezas de madrugada, \\ se va por la calle larga. \\ La convergencia \\ de las aceras \\ se abre y ensancha, para \\ que pase la Nave \\ de nuestro soñar.
}

Como advertimos, y así lo ha señalado Javier Pérez Bazo, la poesía de Chabás de estos años se distingue por un claro hibridismo en el que entran componentes diversos de la tradición estética del momento ${ }^{13}$. El espectáculo urbano de la calle solitaria no impide que estén presentes en él los tranvías, pero a éstos se les otorga un papel sentimental. Es decir que futurismo y un cierto neosimbolismo nostálgico se mezclan en esta singular evocación de Juan Chabás. En Vltra dio a conocer algunos otros poemas: "Farolillo flotante" (21, 1 de enero de 1922), en el que se muestra un nuevo cuadro nocturno, con algún hallazgo imaginístico notable ("La noche apaga sus luces / en todos los caminos", con el que se cierra el poema); "Madrugada" (22, 15 de enero de 1922), en el que prescinde por primera vez del segundo apellido; y "Ondas. Tarde" (24, 15 de marzo de 1922), que lleva el título del libro proyectado y que no llegó a publicar (Nuevamente paisaje y estado de ánimo confluyen entre representaciones vanguardistas de la naturaleza, algunas acertadas: "Y un nácar imposible de arco iris / llenaba de canciones / nuestros ojos"). En Vltra, Chabás también dio a conocer un texto en prosa, titulado "La calle" (23, 1 de febrero de 1922). De todas estas composiciones primigenias, la más interesante es "Madrugada", en la que metáfora vanguardista, greguería e imágenes tradicionales (como lo es la figura del gallo) conjuntan una composición nada desdeñable, en la que intimismo simbolista y paisaje sublimado construyen la escena donde los enamorados juegan con las formas de la naturaleza:

13 J. Pérez Bazo, Juan Chabás y su tiempo. De la poética de vanguardia a la estética del compromiso, p. 54. 
La poesía de Juan Chabás en el contexto de la vanguardia hispánica: tradición ...

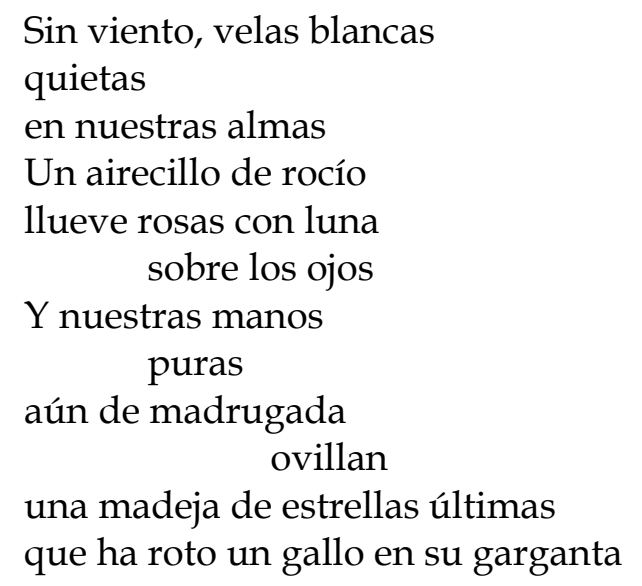

En aquel mismo 1922, Chabás se vio favorecido nada menos que por Juan Ramón Jiménez cuando en el número 4 de su revista Índice ${ }^{14}$ (de 2 de enero) vio recogidos tres poemas suyos, que sorprenden porque son muy diferentes de los aparecidos en Vltra. Se mueve ahora Chabás en los espacios de la más estricta retórica juanramoniana, lo que debió complacer no poco al andaluz universal, al verse retratado en uno de sus discípulos, aunque sólo sea momentáneamente. En este mismo número 4, como en los tres anteriores, otros muchos poetas jóvenes reflejan con nitidez su juanramonismo. Tres poemas de Salinas, que figuran este mismo último número de Índice, (dos de ellos posteriormente corregidos) reflejan esta misma dependencia discipular, de la que afortunadamente el gran poeta madrileño se separaría contundentemente poco más tarde.

He aquí los tres poemas juanramonianos de Chabás, publicados con el título común de "Poemas" y cierta unidad temática, ya que cada uno de ellos se refiere a un tiempo del día. El primero de ellos es "Tarde":

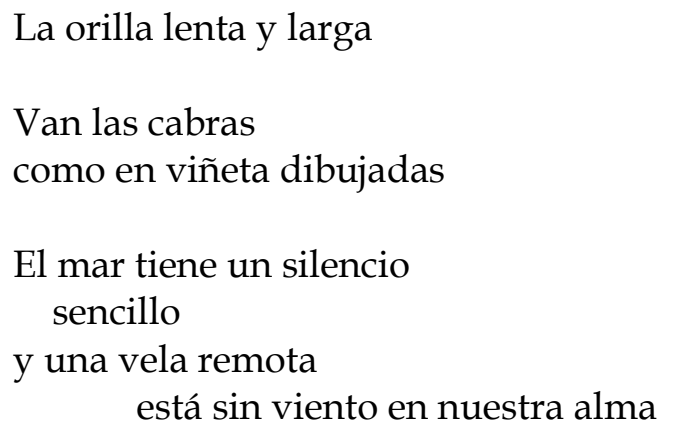

14 Índice (Revista de definición y concordia), Madrid, 1921-1922. Edición de J. Esteban, Madrid, José Esteban Editor-Ediciones del El Museo Universal, 1987. 
Ya la tarde se marcha

cojeando un poquito

Un cascabel de agua

le va diciendo a una cabrita blanca

su madrigal en la garganta

Como puede advertirse, se trata de una estampa neomodernista convertida en una estática representación del paisaje, muy influido en su plasticidad por la poesía pura, que transmite al poema la economía en el uso de la palabra característica en su formulaciones poéticas paisajísticas. Laconismo que afecta incluso, como es el caso de los tres poemas publicados en Índice, a los títulos de las composiciones. El alma, como receptora y beneficiaria de los efectos estéticos del paisaje, puede gozarse con los elementos "dibujados" en el poema, como si de un cuadro ("viñeta" se le llama) naïf se tratase. El propio término "dibujadas" forma parte de la arquitectura estética del poema, mientras que los sonidos quedan reducidos al cascabel que se oye en la escena. Todo lo demás es silencio.

Este poema lo volvió a publicar, años más tarde junto a otros dos, titulados “Liliana" y "Viento", en la revista Meseta de Valladolid, pero mucho más extenso. Más bien parece que se continúa con otros poemas añadidos, como si fueran canciones, parecidas a las que incluiría en Verso y Prosa, en 1927. Incluso, se realizan variantes respecto al texto de Índice. He aquí el texto completo, según la revista Meseta, 4, 1928:

La orilla lenta y larga;

van las cabras

como en viñetas dibujadas

El mar tiene un silencio

sencillo

y una vela remota

está sin viento en nuestra alma

Ya la tarde se apaga.

Un cascabel de agua

le va diciendo a una cabrita blanca

su madrigal en la garganta.

Para subir a la cima 
La poesía de Juan Chabás en el contexto de la vanguardia hispánica: tradición ...

yo tenía una canción.

- Rosal de buena palabra, árbol de sombra anchurosa donde tus ojos brillaban.-

El senderito delgado

al mar hondo conducía

entre los almendros blancos.

El monte al lado, la fuente de sol tenía brillante erguida en un cielo alegre.

Por el senderito iba dando la mano al recuerdo de un amor que yo tenía:

Era tu vestido blanco - ¡qué alegría con el viento tu falda en el monte alto! -

Rosal de buena palabra, árbol de sombra anchurosa, cuando volvía hacia el mar el senderito delgado todavía azuleaba con luz de tus ojos claros.

Llévame amor con el viento que ahora hincha mis velas; llévame amor que está cerca de mi mano, ya, el deseo. Luceros está apagando el alba en un cielo alto; junto a la orilla la tierra con rocío se despierta. ¡Llévame amor con el viento como llevas a mi barco! 
La mañana, alegre, estaba

con un rayito de sol

dentro del agua.

¡Y qué deseo, qué ansia

de beberse todo el sol,

con las manos,

en el agua!

Como vemos, son canciones de corte neopopular, muy marineras, y muy de aire libre, prendidas a la naturaleza y dedicadas al amor, canciones galantes muy de la época. Con toda seguridad, la revista unió poemas diferentes, canciones independientes en una sola, cuya primera composición es, justamente la que incluiría Juan Ramón en su revista.

Volviendo a los poemas de Índice, no muy alejado de los mismos supuestos de escuela es "Noche":

\author{
La vela blanca y sonora \\ flameando las estrellas \\ en el agua \\ Viajera \\ iba la luna en tu mirada \\ Y todos los caminos \\ colgábanse de luces \\ al borde de la noche
}

Este "nocturno" aporta, al conjunto de poemas "horarios" la magia de la noche estrellada y lunar. La imagen del satélite, reflejada en la mirada de la destinataria del poema, símbolo, otro más, neomodernista, no impedirá, sin embargo, el violento juego de imágenes con el que la breve composición se cierra. Se trata igualmente de una representación estática del paisaje muy de aquellos años, emparentable con similares construcciones de Aleixandre, Salinas, Prados, Guillén...

Y, por último, "Mediodía”, en el que el modelo de Juan Ramón Jiménez se advierte aún más:

Un sol de agrias notas rompe

sus cristales de oro

en el mar de las doce 
La poesía de Juan Chabás en el contexto de la vanguardia hispánica: tradición ...

\author{
Pulsa el viento sonoro \\ estradivarius en las velas \\ Y hay en el alma una alegría \\ de diamantes encendidos \\ por la luz de mediodía.
}

Es un poema definitivamente adscribible a lo que podríamos denominar más estricta poesía pura, ligada al maestro Juan Ramón. Las metáforas formales, la referencia al tiempo por medio del reloj, la transformación de los sonidos naturales en sonidos instrumentales (con una antonomasia muy del gusto parnasiano de los jóvenes modernistas) y, sobre todo, la presencia del alma como sujeto paciente del entusiasmo ante el paisaje, adscriben plenamente este poema a la estética más pura de la poesía española de los años veinte. La economía verbal, antes señalada, advertible incluso en el título del poema y la mínima acción, hace que la plasticidad de la composición se acentúe de forma extraordinaria.

Todavía en 1922, en el misterioso número 1 de Horizonte ${ }^{15}$, cuya fecha desconocemos, aunque se supone publicado en noviembre de aquel año (hasta 1987 nadie modernamente había visto tal primer número de la revista), Chabás daría a conocer dos poemas, titulados "Madrigal" y "Eco", que hasta hace poco estaban absolutamente ignorados por la crítica especializada ${ }^{16}$; $\mathrm{y}$, en efecto, son dos poemas del máximo interés para seguir la evolución de Chabás que busca, en este momento, una expresión personal. Preside a los dos poemas el título de "Ondas", naturalmente el del libro que proyecto y no llegó a editar, aunque se anuncia todavía en enero de 1923, en los tres poemas que recogerá el número 4 de Horizonte, titulados "Tormenta", "Tristeza" y "Arco-Iris", y firmados con el nombre de "Juan Chabás", mientras que los del número 1, van firmados por J. Chabás y Martí. Volviendo a éstos, advertimos las mismas características ya señaladas para los tres poemas de Índice. Así "Madrigal":

Se riza en tus cabellos la mañana

alegre de mar y sol.

Y en tus ojos la brisa

juega con tus sonrisas.

${ }^{15}$ Horizonte, edición de J. M. Barrera, Sevilla, Renacimiento, 1991.

${ }^{16}$ José María Barrera lo explica en su prólogo a la edición facsímil, pp. 6-7. 
Bajo de tu sombrilla,

iluminan la sombra tus palabras

y mis versos te besan las mejillas.

Sobre tu falda,

vas deshojando con las manos

tus canciones.

Es muy curioso observar, en el poema antes trascrito, el valencianismo que a Chabás se le ha deslizado a la hora de utilizar la preposición bajo (que también utilizaba su comprovinciano alicantino, el gran Gabriel Miró), en función adverbial, dialectalismo habitual en los valenciano-parlantes aún persistente. Como vemos, se trata de una canción galante de las que Chabás escribió tantas: la naturaleza, el mar, el sonido de la canción, la metaforización barroca, de origen vanguardista, pero muy sugerente y también habitual en la poesía pura de los grandes poetas del momento, crean el ambiente apetecido, en el que el sentimiento de atracción hacia la amada se funde con una naturaleza espléndida, mientras los amados se intercambian palabras (de amor) y canciones. El otro poema, "Ec" insiste en lo ya señalado respecto a la contemplación de la naturaleza, ahora una noche estrellada en el mar, mientras metáforas muy expresivas crean un ambiente con sonido como en el poema anterior. Mientras en aquel eran las palabras y las canciones, ahora es el eco el que compone el fondo acústico del poema:

Estrellas

arpas de la noche

en el fondo del mar

cantando

se va y viene el eco

columpio del viento,

eco marinero

rodando en el cielo.

Al derecho y al revés, como la onda va y viene,

se va y viene el eco

columpio del viento; 
La poesía de Juan Chabás en el contexto de la vanguardia hispánica: tradición ...

eco marinero

rodando en el cielo.

Como se advierte, Chabás, siguiendo la tradición secular de los poemas dedicados al "Eco", reproduce la acústica del fenómeno repetitivo con reiteraciones de versos y sintagmas en forma de rueda o círculos concéntricos sugeridores del objeto evocado en el poema, lo que le concede un encanto especial, aquí bastante conseguido desde el punto de vista rítmico, al menos.

En el "Suplemento Literario" de La Verdad, de 9 de marzo de 1924 (número 9), se recoge esta "Canción", que firma J. Chabás y Martí:

Eras, tan sólo, brisa.

Todas tus palabras

temblaban en el mar

y un momento se iban

contigo,

con la brisa

lejos.

Te decían adiós todas las velas

En la otra playa azul del horizonte.

Tú

Eras tan sólo

Brisa.

Que vemos que insiste en el prototipo de canción marinera en la que Chabás, hombre de litoral levantino, sin duda se especializa. Son como acuarelas, leves marinas, en las que siempre hay un motivo sonoro, en este caso, otra vez las palabras de la amada, que lleva la brisa, la misma brisa que empuja a los veleros que surcan el horizonte, en el que se dibujan. En el mismo Suplemento Literario de la Verdad, en el de 15 de junio de 1924, y con la misma firma aparece el poema titulado "Valle":

Toda la mañana rodaba hacia el mar.

Pero el pueblo estaba

en el valle hundido. 
- Paz en las casas que tienen cipreses

y el agua de la fuente

y los olivos-.

\section{Subía al cielo, desde el pueblo, una campana.}

Nuevamente, el mar a lo lejos para enmarcar una bella pintura de lejanía de un pueblo hundido en el valle, con su sonido, en este caso las campanas que se oyen a lo lejos. Pérez Bazo ha señalado que este poema confirma "la adscripción de Chabás a la lírica tradicional, iniciada con sus "Poemas del Valle de Polop", extensa composición con cuatro partes o "momentos" inserta en las páginas de España, en 1923" 17.

Chabás siguió publicando en los años siguientes poemas de este mismo corte cancioneril y galante, de tipo tradicional, con representaciones caracterizadas por la brevedad del verso y las sugerencias paisajísticas especialmente marineras. Uno de los poemas de Índice, antes trascrito, se iniciaba con una referencia a la "orilla lenta". Pues bien "Orilla lenta", sugerencia de mar en clama, es el título elegido para la serie de cuatro poemas, numerados en romanos, que Chabás publica en Papel de Aleluyas, en su número 6 de abril de 1928 18. Responden estos cuatro textos a otras tantas representaciones de la naturaleza: la tormenta, la mañana, el anochecer y la despedida:

$\quad$ En el corazón me grita
la tormenta,
medroso un trueno me rueda
por el alma
y en el pecho se encabrita
una ola
que me ahoga
esta canción marinera.
Nubarrones de agua y viento
el cielo hacia el norte arrastran
y el horizonte de miedo

17 J. Pérez Bazo, Juan Chabás y su tiempo, p. 70.

18 Papel de Aleluyas. Hojillas del Calendario de la Nueva Estética. Huelva, 1927-1928, edición de J. Issorel, Huelva, Instituto de Estudios Onubenses "Padre Marchena”, 1980. 
La poesía de Juan Chabás en el contexto de la vanguardia hispánica: tradición ...

retumba y cierra los brazos.

Obenques y estais se quiebran,

las mayores se desgarran

y crujen todas las jarcias,

bordones de la tormenta.

El cielo cae en el agua;

el mar, una nube negra.

Advertimos en estos poemas que, en esta ocasión firma Juan Chabás, un mayor aliento estructural y una mayor ambición pictórica. En el primero de estos cuadros, destaca la utilización de un lenguaje náutico muy especializado (obenque, estay, jarcia...), lo que pone de relieve que el poeta, natural de Denia, localidad costera y muy marinera, conocía muy bien el ambiente de barcos y pescadores.

II

Entre las manos el alba me cantaba como un pájaro.

De par en par la ventana

- el mar, el cielo y el ríoasomada a un sueño lento

detenía la mañana

a bordo de los navíos.

(Sobre la almohada, despacio,

las olas se mecían con el viento)

Mi barca, con cinco velas:

Ya sin puerto, en alta mar;

entre inconsciencia y desvelo

por los mares de mi sueño.

- ¡Nave del alba, viaje! -

desde el agudo bauprés

levantó el vuelo una estrella.

Se trata de un nuevo cuadro marinero, acuarela de paisaje en el que la mañana se fija a su aparición por la ventana. Al fondo, el mar y los barcos, mientras el poeta va despertando de su sueño, junto a su almohada, en la que se entremezclan olas, viento, barcos. De nuevo, una hora del día es la que enmarca la evocación, mientras el espacio se va poblando de luz, objetos. Nuevamente, 
los modos de la poesía pura (Guillén, Aleixandre, Prados tendrán representaciones de este tipo) son los escogidos para glosar este cuadro matinal.

III

Todas las luces anheladas

y la ciudad arrodillada

sobre el mar:

lento y cansado navegar.

Recuerdos: náufrago lento

por una estela de luna.

Recuerdos:

ya no se cuentan con los dedos, pero los canta el ritmo de los remos.

La noche entorna sus pupilas

sobre el silencio de la mar.

Chabás asume, desde luego, en sus representaciones paisajísticas, modelos muy reiterados en la poesía pura. En este caso, son las personificaciones las que marcan la humanización formal del paisaje: ciudad arrodillada, la noche entornando sus pupilas (como en Jorge Guillén, en "Los nombres", de Cántico: "El horizonte / entreabre sus pestañas / y empieza a ver..."). Aquí es la noche la que nos conduce al silencio, mientras que la retórica del poema ha marcado, por medio de la reiteración, la evocación nostálgica de los recuerdos, vinculados primero a la luna, y después a la única sugerencia de sonido: el ritmo de los remos. Después: silencio, el silencio del mar.

\section{IV}

Ya eras, tan solo, una vela

blanca;

y con el viento te alejabas tanto

que ya te besaban

el cielo y el mar.

Todas las velas del puerto, tendidas

rezaban por ti moviendo sus alas;

- a mí me quedó tu grito

de adiós, sin sentido, agrio,

horadándome el recuerdo

tuyo. 
La poesía de Juan Chabás en el contexto de la vanguardia hispánica: tradición ...

Ibas al cielo por el mar.

De pronto,

la vela tuya pareció volar.

Por último, el poema que cierra la serie (nueva estampa marinera) nos introduce en la expresión de anhelos o deseos más personales, vinculados a una despedida, metaforizada en la vela de un barco que se aleja hasta perderse. Apartándose un tanto de la poesía pura más estricta, la sentimentalidad (grito de adiós... horadándome el recuerdo tuyo...) rompe la frialdad de la evocación, apasionándola. Este poema y, en conjunto, la serie también sobresale, desde el punto de vista argumental, debido a la superior extensión de las composiciones que permite al poeta establecer una mayor riqueza episódica, aunque permanecen el mismo tono de cuadro marinero, envuelto en el ensueño imaginativo, característico de toda la poesía de Chabás en estos años, en los que no faltó alguna sorpresa curiosa, sin duda debido a lo repetido de los tonos y los climas de sus pequeños poemas marineros.

En efecto, en la Tontología, que reunió Gerardo Diego, de forma jocosa y divertida, en su revista Lola ${ }^{19}$, en 1928, se recogen, firmadas por Dámaso Alonso, dos "Coplas", de las que se indica que están publicadas en Verso y Prosa, número 5. Pero Dámaso Alonso no publicó ningún poema en Verso y Prosa. Únicamente, su prosa, no recogida en Obras completas, "Acuario en virgo". Las dos "Coplas" merecedoras de figurar en la curiosa antología de poemas "tontos" son de Juan Chabás, y son las siguientes:

Toda la noche he tenido en mi regazo un lucero; cuando se quedó dormido lo envolví con un pañuelo.

Y la otra:
Ábreme los ojos sobre este dolor, acaricialó con tu claridad.

\footnotetext{
19 Carmen. Revista Chica de Poesía. Lola, Amiga y Suplemento de Carmen, edición de G. Diego, Madrid, Taurus, 1977.
} 
De manera que podemos confirmar la "participación" de Juan Chabás en la famosa Tontología, en la que comparte páginas con Antonio y Manuel Machado, Juan Ramón Jiménez, E. Díez-Canedo, Ramón Pérez de Ayala, Pedro Salinas, Jorge Guillén, Gerardo Diego, Manuel Altolaguirre, Federico García Lorca, Dámaso Alonso y Rafael Alberti. La Tontología se escribe recogiendo poemas tontos no de poetas malos, sino de poetas consagrados, porque-dice "El Tontólogo" (Gerardo Diego) - resulta "de una conmovedora edificación el recoger algunos de los muchos resbalones de los poetas capaces de escribir versos buenos." Pues bien, entre ellos, se encuentra Juan Chabás, aunque su nombre no figure, ya que él es, y no Dámaso, el firmante de las canciones en Verso y Prosa.

Debemos preguntarnos e intentar comprender el significado de esta importante "errata de imprenta", que no creemos en absoluto inocente. Chabás, sin duda, como tantos otros de mayor categoría que él (pensemos en Juan Ramón Jiménez, cuyo disgusto por su inclusión en la Tontología manifestó a su fiel Juan Guerrero Ruiz), fue elegido por el grupo de amigos para figurar en el peregrino florilegio de Lola, pero a la hora de incluirlo, un duende de imprenta atribuyó estos poemas a otro, al que fuera, daba lo mismo, cualquiera servía menos el nombre de Juan Chabás, que, sin duda (estamos en el terreno de la broma) fue sustituido para evitar los maleficios de gafe que tantos le atribuían. En Lola no hay erratas, ya que Gerardo Diego era especialmente cuidadoso. De esta forma, la broma para Chabás fue doble: fue incluido en la Tontología y además fue escamoteado su nombre al pie de poemas que, en fin, eran hijos suyos.

He aquí el resto de las canciones recogidas por la revista murciana, en su número 5, 1927, en la única colaboración en verso que Chabás publicó en la revista. Sus otras colaboraciones son un artículo en prosa, "Góngora en expreso" (número 6, 1927), en el homenaje al poeta cordobés, y tres fragmentos de novelas ("El amor anclado", número 1, 1927; "Caleta de sombra", número 8, 1927; y "Trozo", número 11, 1928), colaboración habitual ya en estos años de Chabás en las revistas de la época, como en Litoral 20, donde publicó "Intermedio" (Número 3, marzo de 1927). El conjunto completo de las canciones incluidas en Verso y Prosa quedó así:

20 Litoral, edición facsímil, Málaga 1926. México 1944, edición de Á. Caffarena, Málaga, Ayuntamiento de Málaga, 1990. 
La poesía de Juan Chabás en el contexto de la vanguardia hispánica: tradición ...

Yo no sé que fuente clara me dijo aquella canción.

"Lo mismo que brota el agua te ha de brotar el amor".

\section{II}

Toda la noche he tenido en mi regazo un lucero; cuando se quedó dormido lo envolví en un pañuelo.

III

Los lucerillos de Santa Lucía tienen de agua de mar las pupilas; los lucerillos de Santa Lucía siempre se duermen y no ven el día.

\section{IV}

De mantilla viene

la madrugada:

de mantilla viene

muy nubarrada.

\section{V}

Ábreme los ojos
sobre este dolor,
acaricialó
con tu claridad.

VI

Prendido del alto cielo

el ramaje de mi anhelo;

¡más la virtud de mi vida 
aquí en la tierra, qué hundida!

VII

Hacia la aurora mi sueño

vino con la campanita

que me trajo tu recuerdo-

¡Torre del convento, limpia!

Como se advierte, Chabás sigue fiel, independientemente del criterio de Gerardo Diego y sus amigos, al escoger dos de estas canciones para la Tontología, al tipo de verso galante con una fuerte presencia de la contemplación de la naturaleza en sus diversas fases, con fondo marinero: de la noche al día, con presencia del amanecer (la aurora, la madrugada) y presencia de pequeños nocturnos, en el que brilla la magia de la luz de las estrellas o los luceros. Las notas de sonido vuelven a completar alguno de estos cuadros, mientras en todos ellos la versificación breve llena de gracia las diversas evocaciones de la naturaleza.

En Meseta, además del poema transcrito antes, figura, "Liliana", un poema muy extenso, formado por una canción inicial y por uno de los cuatro poemas recogidos en Papel de Aleluyas:

- “en la mano tengo el mar;

mi bolsillito de nácar,

la sortija esmeralda

y mi pañuelo pintado." -

- ¡Ohincé como navegamos! -

¡ El mar pañuelo de seda,

tiene pintada una luna

y un barco de velas!

— ¡Ohincé que lejos de tierra! -

- “'Si llegará a España el barco

que tiene siete velas

pintadas en mi pañuelo!" - 
La poesía de Juan Chabás en el contexto de la vanguardia hispánica: tradición ...

Se le dora la melena

con un reflejo el faro.

- ¡Ohincé que lejos del puerto! -

Entre las manos el alba me cantaba como un pájaro.

De par en par la ventana - el mar, el cielo y el ríoasomada a un sueño lento detenía la mañana a bordo de los navíos.

Sobre la almohada, despacio, olas de viento mecían mi barca con cinco velas.

Ya sin puerto, en alta mar; entre inconsciencia y desvelo por los mares de mi sueño.

Nave del alba, ¡viaje!

Desde el agudo bauprés levantó el vuelo una estrella.

El último de los poemas de Meseta, titulado "Viento", recupera modos iniciales basados en el ritmo ligero y en los aires galantes $\mathrm{y}$, como siempre o casi siempre, marineros. Los elementos de sonido y las metáforas de ascendencia vanguardista o neobarroca no faltan:

El viento en los pinos, lleno

de la gracia de tus ondas

Ya se va el rumor y viene velero siempre; velero como el alma en tu pupila. 


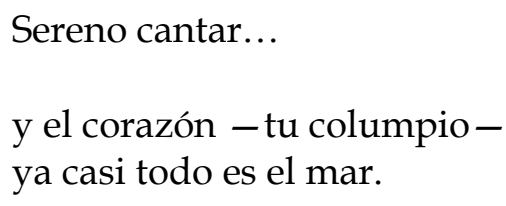

En los años que nos ocupan, debemos destacar, para terminar, algunas poesías publicadas algo distintas de las que hemos visto, ya que Chabás también cultivó, aunque con menos gracia, el poema homenaje o poema de circunstancias, que tiene mucho menos interés que las canciones transcritas. Así, en la revista Alfar, número 56, de marzo de 1926, publicó cinco sonetos, tres de ellos, dedicados, respectivamente, a algunos comprovincianos famosos, como el músico Oscar Esplá, el escritor Gabriel Miró, y el pintor Lorenzo Casanova.

La aventura literaria de Chabás continuó a través de los años y de las publicaciones. En las distintas etapas de su vida acentuó su cultivo de un género $\mathrm{u}$ otro, pero fundamentalmente, como hemos señalado, novela y estudios literarios. A la poesía no volvió de forma continuada sino esporádicamente, y, dicho sea con todo el rigor, ya sin el encanto que tienen las composiciones juveniles, vacilantes, que hemos transcrito completas en este trabajo por ser tan poco conocidas, por estar relegadas al olvido más absoluto, a pesar de responder a los alientos que dieron tanta fama a otros compañeros de generación, hoy consagrados canónicamente para la historia literaria como máximos representantes de la poesía española del siglo $X X$.

Chabás no fue un poeta mediocre ni un poeta secundario ni un poeta menor. Chabás fue un poeta inteligente que no encontró su camino: se inició en el ultraísmo, pero sin apartarse de la inmediata herencia del simbolismo, e incluso del modernismo más directamente vinculado a Rubén (como se evidencia en una lectura simbolista de su libro ultraísta Espejos), practicó la imagen creacionista e intentó forjar poemas de la más estricta vanguardia (maquinismo, tecnología), mientras que se dejó influir por la greguería, para luego abrazar la poesía pura y terminar recreándose en una lírica neopopularista o de tipo tradicional, en la que funde modelos de vanguardia y poesía pura. Y todo, en un período temporal de escasos años, entre 1920 y su marcha a Génova, en 1925. Cuando Chabás regresa de Italia ha comprendido que su anhelo de ser poeta no ha dado los frutos esperados. Tras probarlo todo, no ha encontrado su camino. 